\title{
Effect of Modified Atmosphere Packaging on Postharvest Quality of Mango cvs. Sindhri and Sufaid Chaunsa During Storage
}

\author{
Omer Hafeez Malik ${ }^{1 *}$, Aman Ullah Malik ${ }^{1}$, Muhammad Shafique Khalid ${ }^{2}$, Muhammad Amin ${ }^{3}$, \\ Samina Khalid ${ }^{2}$, Muhammad Umar ${ }^{4}$
}

${ }^{1}$ Postharvest Research and Training Centre (PRTC), Institute of Horticultural Sciences, University of Agriculture Faisalabad, Faisalabad, 38040 Punjab, Pakistan

${ }^{2}$ Department of Environmental Sciences, COMSATS Institute of Information Technology, Multan Road Vehari, 61100 Punjab, Pakistan ${ }^{3}$ Department of Horticulture, Muhammad Nawaz, Sharif University of Agriculture Multan, Old Shujabad Road Multan, 60000 Punjab, Pakistan

${ }^{4}$ Tasmanian Institute of Agriculture, University of Tasmania, Australia

\section{A R T I C LE IN F O}

Article history:

Received 02 June 2016

Accepted 14 October 2016

Available online, ISSN: 2148-127X

Keywords:

Mangifera indica

Fungicidal dipping

Hot water treatment

Firmness

Modified Atmosphere

${ }^{*}$ Corresponding Author:

E-mail: omerhafeez10@yahoo.com \begin{abstract}
A B S T R A C T
Modified atmosphere packaging (MAP) technology is gaining popularity worldwide for its potential of extending shelf life of fresh produce with better fruit quality. Effect of MAP (using Xtend ${ }^{\circledR}$ bags), was investigated on postharvest storage life and quality of mango cvs Sindhri and Sufaid Chaunsa stored at $11^{\circ} \mathrm{C}$ with $80-85 \% \mathrm{RH}$ for 4 and 5 weeks respectively, in comparison with un-bagged (control) fruit. Uniform physiological mature fruit of Sindhri and Sufaid Chaunsa were harvested from a commercial mango orchard along with $4-5 \mathrm{~cm}$ long pedicel and were de-sapped in $0.5 \%$ lime solution (to avoid sap burn injury). Later on fruit were given cold water fungicidal dip (Sportak @ $0.5 \mathrm{ml} / \mathrm{L}$, Active Ingredient: Prochloraz) followed by hot water treatment $\left(52^{\circ} \mathrm{C} ; 5 \mathrm{~min}\right)$. After shade drying and pre-cooling $\left(11^{\circ} \mathrm{C} ; 10-12\right.$ hours $)$, fruit were packed according to the treatment combination and stored at $11^{\circ} \mathrm{C}$. Fruit of both varieties were removed after 2,3 and 4 weeks of storage followed by ripening at $24 \pm 2^{\circ} \mathrm{C}$ with an additional removal after 5 weeks for Sufaid Chaunsa only. Fruit quality was evaluated for various biochemical, organoleptic and physical parameters at two stages of ripening (at removal day and at final ripening day). Fruit of both varieties stored in MAP exhibited better firmness and retained green colour as compared to un-bagged fruit. Quality of fruit subjected to postharvest fungicidal application and hot water treatments and stored under MAP at $11^{\circ} \mathrm{C}$ showed better peel colour development and less disease development. Moreover, storage durations and post storage ripening stages significantly affected fruit peel colour, textural softness and disease development. Further, cv. Sindhri showed better storage potential with lower disease incidence as compared to cv. Sufaid Chaunsa which warrants further studies on disease control aspects.
\end{abstract}

\section{Introduction}

Mango (Mangifera indica L.) fruit is considered a highly cherished and important economical fruit in tropics and subtropics of the world. Production of mango has gained commercial importance in more than 87 countries. India, China, Thailand, Indonesia, Philippines, Pakistan and Mexico are among renowned producers of mango (Tharanathan et al., 2006). Pakistan is ranked sixth largest exporter of mango with export quantity of 84.9 thousand tons with estimated value of 29.3 million US dollars (Anonymous, 2010). Over the last decade, world-wide increase in fresh mango trade has been observed due to the advancements in postharvest handling technology, improvements in logistics and communication. At present, the mango exports from Pakistan are predominantly to UAE, Saudi Arabia, Kuwait, Iran, China and UK (Hafeez et al., 2012).
The market of any fresh produce including mango is directly related to the quality of that particular produce throughout the supply chain. Pakistani mangoes have found their way in the super markets of EU and UK due to improvement in quality by extensive research work both in pre and postharvest areas (Johnson et al., 2013). Mostly, mangoes are exported by air which is no doubt costly and allows only a limited quantity of fruit to be exported. Preferably, sea shipping can be used as an alternative method for exporting mango fruit to distant markets. Main advantage, for this sea shipping, is low sea freight charges (Rs. 20/kg as compared to Rs. $120 \mathrm{~kg}$ of air freight: Karachi to UK) with an additional benefit of exporting bulk volumes of commodity which is not possible in air freight. 
However, some problems are associated with this economical way of sea transportation. Sea shipping takes much longer time than air freight to reach the destination. Moreover, there is always issue of the maintenance of fruit quality through sea transport chain to end consumer. Mango is a climacteric fruit hence; sea shipping is a challenge due to its limited shelf life. In normal cold storage, mangoes can be stored up to 3 weeks (Hafeez et al., 2012). To extend the shelf life of mango and to make use of the benefits related to sea shipping, the use of modern storage technologies is mandatory.

MAP is a unique technique used for enhancing the storage and shelf life of fresh or processed fruits, vegetables and other perishable commodities (Parry, 1993). MAP was used for the first time in 1927 to extend the shelf life of apples by storing them in atmospheres with reduced oxygen and increased carbon dioxide concentrations (Davies, 1995). The extension of storage and shelf life is one of the most obvious benefits of MAP. A high respiration rate usually results in shorter storage and shelf life. The respiration rate of the produce is influenced by storage temperature, produce variety, growing area and conditions and injury to the produce (Day, 1989). Natural deterioration of the product is slowed down in MAP storage (Day, 1990). By decreasing the amount of available oxygen to the produce, respiration rate and rate of all metabolic processes are correspondingly decreased resulting in delay of ripening and senescence. Mango has been reported to have good response to MA storage at more advanced stage of ripening (Beaudry et al., 1992). The main factors that maintain mango quality in various film packaging are increased $\mathrm{CO}_{2}$ and decreased $\mathrm{O}_{2}$ levels which reduce respiration rate and prevent water loss (Kader, 1994). Packaging of 'Tommy Atkins' mango in perforated polyethylene film delayed fruit spoilage and allowed normal ripening together with a weight loss reduction by half and prevention of fruit shriveling (Kader, 1994). Moreover, the postharvest life of mangoes can be extended by the combination of MAP with effective decay-controlling measures (Rodov et al., 1997).

However, the scientific information regarding the effect of MAP (Xtend $\AA$ bags) on commercial mango cvs of Pakistan is not available. Therefore, this study was designed to evaluate the behaviour of commercial Pakistani mango cv. Sindhri and Sufaid Chaunsa under MAP, so as to build prospects for using this storage technique for exporting Pakistani mangoes to distant markets.

\section{Material and Methods}

Plant Material, Treatments Application and Removal Schedule for Mango $\mathrm{cv}$. Sindhri

Uniform sized and physiologically mature fruit of mango cv. Sindhri were collected from a commercial mango orchard located at Lodhran, a District of Punjab Province $\left(29^{\circ} 15^{\prime} 25 \mathrm{~N} ; 7^{\circ} 32^{\prime} 60 \mathrm{E}\right)$, Pakistan (H.D: June 10, 2010). Fruit were harvested along with $4-5 \mathrm{~cm}$ long pedicels. Just after harvesting, fruit were de-sapped in $0.5 \%$ lime solution to avoid sap burn injury. After desapping fruit were subjected to cold water fungicidal application (Sportak @ $0.5 \mathrm{ml} / 1$, Active Ingredient: Prochloraz) followed by hot water treatment $\left(52^{\circ} \mathrm{C} ; 5\right.$ min) to reduce the incidence of disease development during storage. Fruit were pre-cooled to $11^{\circ} \mathrm{C}$. Modified atmosphere bags (Xtend ${ }^{\circledR}$ bags) were used for bagging fruit. Two treatments were made: $\mathrm{T}_{1}$ : Bagged fruit; $\mathrm{T}_{2}$ : Un-bagged fruit. Each treatment unit consisted of three replications with eight fruit (approx. $4-4.5 \mathrm{~kg} / \mathrm{box}$ ) in each replication.

Fruit were removed from cold storage after 2, 3 and 4 weeks of storage in accordance with simulated sea shipment studies. After every removal, fruit were subjected to ethylene ripening, at $24^{\circ} \mathrm{C}(100 \mathrm{ppm} ; 48 \mathrm{hrs})$ followed by five days of shelf studies at $20^{\circ} \mathrm{C}$. Observations were made on three stages (at removal day, after ethylene treatment and at final day of ripening) to check the effect of treatments (bagging) and removals (shipping durations) on peel colour, fruit textural softness and disease incidence.

Plant Material, Treatments Application and Removal Schedule for Mango cv. Sufaid Chaunsa

Uniform sized and physiologically mature fruit of mango cv. Sufaid Chaunsa were collected from a commercial mango orchard located at Lodhran, a District of Punjab Province $\left(29^{\circ} 15^{\prime} 25 \mathrm{~N} ; 71^{\circ} 32^{\prime} 60 \mathrm{E}\right)$, Pakistan (H.D: September 11, 2008). Fruit harvested along with 4$5 \mathrm{~cm}$ long pedicels, were de-sapped in $0.5 \%$ lime solution (to avoid sap burn injury), subjected to cold water fungicidal application $\left(0.5 \mathrm{~mL} \mathrm{~L}^{-1}\right.$ Sportak , Active Ingredient: Prochloraz) followed by hot water treatment $\left(52^{\circ} \mathrm{C} ; 5 \mathrm{~min}\right)$ to reduce the incidence of disease development during storage. Harvested fruit were transported to Postharvest Research and Training Centre, Institute of Horticultural Sciences, University of Agriculture, Faisalabad (Pakistan) in an air conditioned van. Fruit were pre-cooled to $11^{\circ} \mathrm{C}$ for $10-12 \mathrm{hrs}$. Modified atmosphere bags (Xtend $\AA$ bags) were used for bagging fruit, provided by METRO Cash and Carry Pakistan. Two treatments were used: $\mathrm{T}_{1}$ : Bagged fruit; $\mathrm{T}_{2}$ : Un-bagged fruit. Each treatment unit consisted of three replications with eight fruit in each replication.

Fruit were removed after 2, 3, 4 and 5 weeks of storage. Three boxes of bagged fruit and three boxes of un-bagged fruit were removed at each removal time. After removal from cold storage, the bags were removed and fruit were allowed to ripe at $24 \pm 2^{\circ} \mathrm{C}$ along with control ones. Observations were made at two different stages of ripening (at removal day and at final ripening day) to check the effect of treatments (bagging) and removals (shipping durations) on various physico-chemical and organoleptic quality attributes and marketable index of mango fruit.

At ripe stage fruit were subjected to biochemical analysis such as TSS, titratable acidity, vitamin C and sugar content in order to evaluate the internal fruit quality as described by Amin et al. (2007). The percentage of marketable fruit was also calculated. Organoleptic evaluation of ripe fruit was done regarding taste, texture, flavour, pulp colour and aroma (Peryam and Pilgrim, 1957). To measure the respiration rate, one fruit from each replication was randomly selected and placed into a 
sealed plastic jar for $1 \mathrm{hr}$. Respiration rate was determined by measuring $\mathrm{CO}_{2}$ production using a $\mathrm{CO}_{2}$ analyser (Vaisala MI 70, Vaisala Inc., Helsinki, Finland) and expressed as $\mathrm{CO}_{2}$ m.mole $\mathrm{kg}^{-1} \mathrm{~h}^{-1}$. Fruit peel colour, fruit textural softness and disease incidence were estimated by visual observations (Malik and Singh, 2005). Fruit colour was scored from 1 to 5 (1: $100 \%$ green $-0 \%$ yellow; 2 : $75 \%$ green- $25 \%$ yellow; 3: $50 \%$ green- $50 \%$ yellow; 4 : $25 \%$ green-75\% yellow; 5: 0\% green- $100 \%$ yellow). Similarly, fruit textural softness was rated from 1 to 5 score (1: hard; 2: sprung; 3: slightly soft; 4: eating soft; and 5: over ripe). Diseases were recorded from 1 to 5 scale (1: Nill; 2: <5\%; 3: 5-10\%; 4: 10-25\%; and 5: $>25 \%$ ) (Amin et al., 2007). Marketable fruit (MF) percentage (no signs of rot) was calculated out of total fruit basis.

\section{Analysis}

The experiment was arranged in a completely randomized factorial design with two treatments. Data were subjected to analysis of variance (ANOVA) using Statistix 8.1 software, while Least Significant Difference (LSD) test was used to compare differences between treatments at $95 \%$ confidence level of each variable.

\section{Results}

Effect of Treatments (Bagged and Un-bagged) on Postharvest Quality Characteristics of cv. Sindhri at $11^{\circ} \mathrm{C}$

Fruit of mango cv. Sindhri were found to be significantly affected by MAP treatments in terms of various postharvest quality characteristics. MAP significantly affected the peel colour development, textural softness, disease development, respiration rate, marketable fruit percentage, TSS and sugar content (Table 1). Respiration rate was also recorded higher in unbagged fruit as compared to the bagged fruit. Moreover, bagged fruit had lower TSS and sugar content (reducing and total sugars) as compared to un-bagged fruit.

A non-significant relationship was observed regarding the effect of MAP on weight loss, titratable acidity, TSS:TA ratio, vitamin $\mathrm{C}$ content and non-reducing sugars (Table 1). Organoleptic quality characteristics were also non-significantly affected by bagging the fruit except flavour which was significantly affected by MAP treatments (Table 2).

Effect of Treatments (Shipping durations and Ripening stages) on Postharvest Quality Characteristics of $c v$. Sindhri at $11^{\circ} \mathrm{C}$

Shipping durations significantly affected peel colour development, fruit textural softness, disease development, respiration rate, marketable fruit percentage, bio-chemical parameters (TSS, titratable acidity, TSS:TA ratio, vitamin $\mathrm{C}$ and sugar content) and organoleptic parameters (taste, texture, flavour, pulp colour and aroma) (Table 1 and 2).

Fruit removed after second week of storage had fewer score for colour, textural softness, disease development as compared to other removals. Maximum score for colour, textural softness and disease development was observed in fruit removed after four weeks of storage. An increased weight loss percentage and respiration rate was found in fruit removed after two weeks of storage. Weight loss percentage and respiration rate increased in fruit removed after three weeks of storage and maximum weight loss percentage and respiration rate were recorded in fruit removed after five weeks of storage. Fruit removed after two weeks of storage had more percentage of marketable fruit. Percentage of marketable fruit decreased as storage period was extended and a minimum percentage of marketable fruit was observed in fruit removed after four weeks of storage (Table 1).

TSS value of stored fruit increased with increase in shipping duration. Minimum TSS was found in fruit removed after two weeks of storage and which was at par with the TSS value of fruit removed after three weeks of storage. The highest TSS value was recorded in fruit removed after four weeks of storage. A significant impact of storage/storage durations was found on titratable acidity of Sindhri mangoes. Acidity was found minimum in fruit removed after two weeks of storage and maximum content of acidity were found in fruit removed after three weeks of storage. However, titratable acidity value of fruit removed after four weeks of storage were found at par with that of the fruit from other two storage durations. Fruit removed after two weeks of storage had maximum TSS: TA ratio, while minimum ratio was observed in fruit removed after three and four weeks of storage. A significant decrease in vitamin $\mathrm{C}$ content was found in fruit along with the increase in storage durations. Vitamin $\mathrm{C}$ content were found maximum in fruit removed after two weeks of storage while minimum values were recorded in fruit removed after four weeks of storage. Sugar content (reducing, non-reducing and total sugars) of stored mango fruit were significantly affected by storage durations. Reducing and total sugar content were found to increase with the increase in storage duration. Minimum content of reducing and total sugars were observed in fruit removed after two weeks of storage while maximum content of these two sugars were seen after two weeks of storage, and were found at par with the fruit removed after four weeks of storage. Non-reducing sugar content were found maximum in fruit removed after four weeks of storage and were at par with non-reducing sugars of fruit removed after three weeks of storage. Non-reducing sugars were found minimum in fruit removed after three weeks of storage and were also at par with the fruit removed after three weeks of storage (Table 1).

Storage duration significantly affected all organoleptic parameters (Table 2). A decrease in score for all organoleptic parameters was observed as the storage duration was prolonged. Moreover, a significant relationship was also observed between peel colour development, textural softness, disease development and post shipment ripening stages (Table 3). Fruit were found greener and firmer with lower disease development at removal from cold store. Green colour and firmness of fruit gradually lost after ethylene exposure and at ripening day, the fruit were yellow and eatable soft. Disease development progressed with ripening. Least disease development was noticed in fruit at removal day and more at final ripening day. Fruit removed from cold store at removal day had lower respiration rate. An increase in respiration rate was noted after ethylene exposure and 
maximum respiration rate was observed at final ripening day. Weight loss percentage was non-significantly affected by post shipment ripening stages (Table 3 ).

Effect of Treatments (Bagged and Un-bagged) on Postharvest Quality Characteristics of cv. Sufaid Chaunsa at $11^{\circ} \mathrm{C}$

MAP significantly affected the fruit peel colour development (Table 4). Less colour score was recorded for the fruit stored in MAP bags as compared to the unbagged fruit. Non-significant differences were observed regarding the effects of MAP on fruit textural softness, disease development, weight loss and respiration rate (Table 4). MAP had no significant effect on the biochemical parameters except titratable acidity and TSS: TA ratio (Table 4). Acidity percentage was more in unbagged fruit as compared to bagged fruit. TSS: TA ratio was more in bagged fruit as compared to un-bagged fruit. MAP had non-significant effect on organoleptic characteristics except taste and flavour (Table 5). Fruit stored in MAP bags had less score for taste as compared to un-bagged fruit. Higher score for flavour was observed in bagged fruit as compared to un-bagged ones. Moreover, percentage of marketable fruit was higher in bagged fruit as compared to un-bagged ones (Table 4).
Effect of Treatments (Shipping durations and Ripening stages) on Postharvest Quality Characteristics of $\mathrm{cv}$. Sufaid Chaunsa at $11^{\circ} \mathrm{C}$

Shipping durations and ripening stages had significant effect on fruit peel colour and textural softness (Table 4). Higher score for fruit peel colour were recorded in fruit removed after fifth week of storage while lower score for colour were recorded in fruit removed after second week of storage. Score for peel colour of fruit removed after third and fourth week of storage were at par. As far as fruit textural softness was concerned, an increasing trend was observed. Fruit removed after fifth week of storage were found softer followed by fruit removed after fourth, third and second week of storage. Two different stages of ripening had significant effect on colour and softness. Less score for fruit colour and softness was observed at removal day as compared to score for colour and softness at final day of ripening.

Shipping durations and ripening stages significantly affected the disease development (Table 4). It was observed that as the shipping duration was increased more disease development was observed. Disease development was recorded minimum in fruit removed after second week of storage and maximum in fruit removed after fifth week of storage. Moreover, disease development was more at final ripening day as compared to disease incidence at removal day.

Table 1 Effect of different MAP treatments on postharvest quality characteristics of cv. Sindhri at $11^{\circ} \mathrm{C}$

\begin{tabular}{|c|c|c|c|c|c|c|c|}
\hline \multirow{3}{*}{\multicolumn{2}{|c|}{ Postharvest Quality Characteristics }} & \multicolumn{6}{|c|}{ Treatments } \\
\hline & & \multicolumn{3}{|c|}{ Impact of MAP } & \multicolumn{3}{|c|}{ Impact of shipping durations } \\
\hline & & Bagged & $\begin{array}{c}\text { Un- } \\
\text { bagged }\end{array}$ & $\mathrm{P} \leq 0.05$ & 2 weeks & 3 weeks & 4 weeks \\
\hline \multicolumn{2}{|l|}{ Colour (Score) } & $2.42 \mathrm{~B}$ & $2.77 \mathrm{~A}$ & & $2.53 \mathrm{~B}$ & $2.39 \mathrm{~B}$ & $2.87 \mathrm{~A}$ \\
\hline \multicolumn{2}{|l|}{ Softness (Score) } & $2.47 \mathrm{~B}$ & $2.63 \mathrm{~A}$ & & $2.37 \mathrm{~B}$ & $2.45 \mathrm{~B}$ & $2.83 \mathrm{~A}$ \\
\hline \multicolumn{2}{|c|}{ Disease Severity (Score) } & $0.44 \mathrm{~B}$ & $1.00 \mathrm{~A}$ & & $0.50 \mathrm{~B}$ & $0.47 \mathrm{~B}$ & $1.19 \mathrm{~A}$ \\
\hline \multicolumn{2}{|c|}{ Weight Loss $(\%)$} & 5.79 & 6.06 & NS & $0.45 \mathrm{C}$ & $5.60 \mathrm{~B}$ & $11.74 \mathrm{~A}$ \\
\hline \multicolumn{2}{|c|}{ Respiration Rate $\mathrm{CO}_{2}\left(\mathrm{~m}\right.$.mole $\left.\mathrm{kg}^{-1} \mathrm{~h}^{-1}\right)$} & $1.75 \mathrm{~B}$ & $3.13 \mathrm{~A}$ & & $1.14 \mathrm{C}$ & 2.59B & $3.60 \mathrm{~A}$ \\
\hline \multicolumn{2}{|c|}{ Marketable Fruit (\%) } & $76.19 \mathrm{~A}$ & $63.49 \mathrm{~B}$ & & $78.57 \mathrm{~A}$ & $71.43 \mathrm{AB}$ & $59.52 B$ \\
\hline \multicolumn{2}{|c|}{ TSS ( ${ }^{\circ}$ Brix $)$} & $14.06 \mathrm{~B}$ & $15.07 \mathrm{~A}$ & & $13.75 \mathrm{~B}$ & 14.40B & $15.55 \mathrm{~A}$ \\
\hline \multicolumn{2}{|c|}{ Titratable Acidity (\%) } & 0.20 & 0.23 & NS & $0.16 \mathrm{~B}$ & $0.26 \mathrm{~A}$ & $0.23 \mathrm{AB}$ \\
\hline \multicolumn{2}{|c|}{ TSS:TA Ratio } & 73.39 & 70.95 & NS & $86.89 \mathrm{~A}$ & $61.16 \mathrm{~B}$ & $68.45 \mathrm{~B}$ \\
\hline \multirow{3}{*}{ Sugar content $(\%)$} & Reducing & $2.35 \mathrm{~B}$ & $2.84 \mathrm{~A}$ & & $2.22 \mathrm{~B}$ & $2.87 \mathrm{~A}$ & $2.70 \mathrm{~A}$ \\
\hline & Non Reducing & 3.91 & 4.11 & NS & $4.05 \mathrm{AB}$ & $3.64 \mathrm{~B}$ & $4.34 \mathrm{~A}$ \\
\hline & Total & $6.47 \mathrm{~B}$ & 7.17A & & $6.05 \mathrm{~B}$ & $7.27 \mathrm{~A}$ & $7.14 \mathrm{~A}$ \\
\hline \multicolumn{2}{|l|}{ Vit. C (mg/100g) } & 117.19 & 105.01 & NS & $155.90 \mathrm{~A}$ & $112.89 \mathrm{~B}$ & $64.51 \mathrm{C}$ \\
\hline
\end{tabular}

Means not sharing similar letters are significantly different $(\mathrm{P} \leq 0.05)$; NS $=$ non-significant.

Table 2 Effect of different MAP treatments on organoleptic quality characteristics of mango cv. Sindhri at $11^{\circ} \mathrm{C}$

\begin{tabular}{l|rrrrrr}
\hline \multirow{2}{*}{ Organoleptic Characteristics } & \multicolumn{4}{c}{ Treatments } \\
\cline { 2 - 6 } & \multicolumn{3}{c}{ Impact of MAP } & \multicolumn{4}{c}{ Impact of shipping durations } \\
\cline { 2 - 7 } & Bagged & $\begin{array}{c}\text { Un- } \\
\text { bagged }\end{array}$ & P $\leq 0.05$ & 2 weeks & 3 weeks & 4 weeks \\
\hline Taste & 6.33 & 6.02 & NS & $6.58 \mathrm{~A}$ & $6.60 \mathrm{~A}$ & $5.35 \mathrm{~B}$ \\
Texture & 6.27 & 5.96 & $\mathrm{NS}$ & $6.50 \mathrm{~A}$ & $6.52 \mathrm{~A}$ & $5.33 \mathrm{~B}$ \\
Aroma & 5.54 & 5.59 & $\mathrm{NS}$ & $5.79 \mathrm{~A}$ & $6.07 \mathrm{~A}$ & $4.83 \mathrm{~B}$ \\
Flavour & $6.38 \mathrm{~A}$ & $5.97 \mathrm{~B}$ & & $6.73 \mathrm{~A}$ & $6.67 \mathrm{~A}$ & $5.13 \mathrm{~B}$ \\
Pulp Colour & 6.44 & 6.37 & $\mathrm{NS}$ & $7.13 \mathrm{~A}$ & $6.47 \mathrm{~B}$ & $5.62 \mathrm{C}$ \\
\hline
\end{tabular}

Means not sharing similar letters are significantly different $(\mathrm{P} \leq 0.05)$; NS $=$ non-significant. 
Table 3 Effect of different post shipment stages on physical quality characteristics of mango cv. 'Sindhri'

\begin{tabular}{|c|c|c|c|c|}
\hline \multirow{2}{*}{$\begin{array}{l}\text { Physical Quality } \\
\text { Characteristics }\end{array}$} & \multicolumn{4}{|c|}{ Stages } \\
\hline & At Removal & After Ethylene & At Ripening & $\mathrm{P} \leq 0.05$ \\
\hline Colour (Score) & $1.24 \mathrm{C}$ & $2.53 \mathrm{~B}$ & $4.01 \mathrm{~A}$ & \\
\hline Softness (Score) & $1.40 \mathrm{C}$ & $2.25 \mathrm{~B}$ & $4.00 \mathrm{~A}$ & \\
\hline Disease Severity (Score) & $0.22 \mathrm{~B}$ & $0.74 \mathrm{AB}$ & $1.21 \mathrm{~A}$ & \\
\hline Weight Loss $(\%)$ & 5.34 & 6.49 & 5.95 & NS \\
\hline Respiration Rate* & $1.68 \mathrm{C}$ & $2.22 \mathrm{~B}$ & $3.43 \mathrm{~A}$ & \\
\hline
\end{tabular}

Table 4 Effect of different MAP treatments on postharvest quality characteristics of cv. Sufaid Chaunsa at $11^{\circ} \mathrm{C}$

\begin{tabular}{|c|c|c|c|c|c|c|c|c|c|}
\hline \multirow{3}{*}{\multicolumn{2}{|c|}{$\begin{array}{l}\text { Postharvest Quality } \\
\text { Characteristics }\end{array}$}} & \multicolumn{8}{|c|}{ Treatments } \\
\hline & & \multicolumn{3}{|c|}{ Impact of MAP } & \multicolumn{5}{|c|}{ Impact of shipping durations } \\
\hline & & Bagged & Un-bagged & $\mathrm{P} \leq 0.05$ & 2 weeks & 3 weeks & 4 weeks & 5 weeks & $\mathrm{P} \leq 0.05$ \\
\hline \multicolumn{2}{|c|}{ Colour (Score) } & $3.08 \mathrm{~B}$ & $3.47 \mathrm{~A}$ & & $2.89 \mathrm{C}$ & $3.30 \mathrm{~B}$ & $3.26 \mathrm{~B}$ & $3.62 \mathrm{~A}$ & \\
\hline \multicolumn{2}{|c|}{ Softness (Score) } & 2.97 & 2.88 & NS & $1.98 \mathrm{C}$ & $3.05 \mathrm{~B}$ & $3.18 \mathrm{~B}$ & $3.48 \mathrm{~A}$ & \\
\hline \multicolumn{2}{|c|}{ Disease Severity (Score) } & 1.60 & 1.12 & NS & $0.33 \mathrm{~B}$ & $1.41 \mathrm{~B}$ & $1.49 \mathrm{~A}$ & $2.19 \mathrm{~A}$ & \\
\hline \multicolumn{2}{|c|}{ Weight Loss $(\%)$} & 4.78 & 4.89 & NS & $3.08 \mathrm{C}$ & $4.62 \mathrm{~B}$ & $5.74 \mathrm{AB}$ & $5.92 \mathrm{~A}$ & \\
\hline \multicolumn{2}{|c|}{ Respiration Rate* } & 2.49 & 2.87 & NS & $2.87 \mathrm{AB}$ & $2.28 \mathrm{~B}$ & $3.16 \mathrm{~A}$ & $2.41 \mathrm{~B}$ & \\
\hline \multicolumn{2}{|c|}{ Marketable Fruit (\%) } & $75.00 \mathrm{~A}$ & $66.67 \mathrm{~B}$ & & $90.47 \mathrm{~A}$ & $83.33 \mathrm{~A}$ & $66.67 \mathrm{~B}$ & $42.86 \mathrm{C}$ & \\
\hline \multicolumn{2}{|c|}{ TSS (Brix) } & 20.80 & 21.06 & NS & 20.50 & 21.03 & 20.85 & 21.34 & NS \\
\hline \multicolumn{2}{|c|}{ Titratable Acidity (\%) } & $0.38 \mathrm{~B}$ & $0.41 \mathrm{~A}$ & & $0.48 \mathrm{~A}$ & $0.43 \mathrm{~B}$ & $0.36 \mathrm{C}$ & $0.28 \mathrm{D}$ & \\
\hline \multicolumn{2}{|c|}{ TSS:TA Ratio } & $59.87 \mathrm{~A}$ & 53.47B & & $42.05 \mathrm{C}$ & $48.14 \mathrm{C}$ & $57.97 \mathrm{~B}$ & $78.51 \mathrm{~A}$ & \\
\hline \multirow{3}{*}{$\begin{array}{l}\text { Sugar } \\
\text { content } \\
(\%)\end{array}$} & Reducing & 2.21 & 2.25 & NS & $2.84 \mathrm{~A}$ & $2.26 \mathrm{~B}$ & $1.94 \mathrm{~B}$ & $1.89 \mathrm{~B}$ & \\
\hline & Non Reducing & 9.25 & 9.19 & NS & $5.79 \mathrm{~B}$ & $8.40 \mathrm{~A}$ & $5.91 \mathrm{~B}$ & $6.43 \mathrm{~B}$ & \\
\hline & Total & 6.69 & 6.58 & NS & 8.94B & $11.10 \mathrm{~A}$ & $8.16 \mathrm{~B}$ & $8.66 \mathrm{~B}$ & \\
\hline \multicolumn{2}{|c|}{ Vit. C (mg/100g) } & 20.43 & 21.50 & NS & $31.18 \mathrm{~A}$ & $24.72 B$ & $18.27 \mathrm{C}$ & 9.67D & \\
\hline
\end{tabular}

${ }^{*} \mathrm{CO}_{2}\left(\mathrm{~m} . \mathrm{mole} \mathrm{kg}^{-1} \mathrm{~h}^{-1}\right)$, Means not sharing similar letters are significantly different $(\mathrm{P} \leq 0.05) ; \mathrm{NS}=$ non-significant.

Weight loss was significantly affected by shipping durations and ripening stages (Table 4). Percentage of weight loss was minimum in fruit removed after second week of storage and was maximum in fruit removed after fifth week of storage. At removal day less weight loss percentage was observed as compared to weight loss percentage on final day of ripening.

Shipping durations significantly affected the sugar content of stored fruit (Table 4). Percentage of total sugar content was maximum in fruit removed after third week of storage. While minimum percentage of total sugar content was observed in fruit removed after fourth week of storage, which was at par with the percentage of total sugar content of fruit removed after second and fifth week of storage. Reducing sugar percentage was higher in fruit removed after second week of storage. Percentage of reducing sugar content removed after third, fourth and fifth week of storage were at par. Higher percentage of non-reducing sugar content was observed in fruit removed after third week of storage. Percentage of non-reducing sugar content of fruit removed after second, fourth and fifth week of storage were at par.

Percentage of acidity, vitamin C content and TSS: TA ratio were significantly affected by shipping durations (Table 4). As the storage period increased, a gradual decrease in vitamin $\mathrm{C}$ content and acidity percentage was observed. Acidity and ascorbic acid content were maximum in fruit removed after second week of storage followed by fruit removed after third, fourth and fifth week of storage, respectively. TSS: TA ratio increased with increase in storage period. The ratio was more in fruit removed after fifth week of storage while it was less in fruit removed after second week of storage. Shipping durations had a non-significant effect on TSS (Table 4).

Organoleptic parameters were significantly affected by shipping durations (Table 5). The score for taste, texture, aroma, flavour and pulp colour was more in fruit removed after second week of storage and was lower in fruit removed after fifth week of storage. Overall, the score for organoleptic parameters decreased as the storage period was increased showing an inverse relationship with storage period.

Shipping durations significantly affected the marketable fruit percentage which decreased as the storage period increased (Table 4). It was quite obvious that percentage of marketable fruit was higher in fruit removed after second week of storage and this percentage decreased as the storage period increased up to five weeks.

Bagging affected the respiration rate of stored mango fruit non-significantly (Table 4). The shipping durations and ripening stages had significantly affected the respiration rate (Table 6). Respiration rate was higher in fruit removed after fourth week of storage and was at par with the $\mathrm{CO}_{2}$ production of fruit removed after second week of storage. $\mathrm{CO}_{2}$ production of fruit removed after second, third and fifth week of storage was at par. Minimum $\mathrm{CO}_{2}$ was observed at removal day than at final day of ripening. 
Table 5 Effect of different MAP treatments on organoleptic quality characteristics of cv. Sindhri at $11^{\circ} \mathrm{C}$

\begin{tabular}{|c|c|c|c|c|c|c|c|}
\hline \multirow{3}{*}{ Organoleptic Characteristics } & \multicolumn{7}{|c|}{ Treatments } \\
\hline & \multicolumn{3}{|c|}{ Impact of MAP } & \multicolumn{4}{|c|}{ Impact of shipping durations } \\
\hline & Bagged & Un-bagged & $\mathrm{P} \leq 0.05$ & 2 weeks & 3 weeks & 4 weeks & 5 weeks \\
\hline Taste & $4.23 \mathrm{~B}$ & $4.71 \mathrm{~A}$ & & $6.33 \mathrm{~A}$ & $4.11 \mathrm{~B}$ & $3.83 \mathrm{BC}$ & $3.60 \mathrm{C}$ \\
\hline Texture & 4.21 & 4.55 & NS & $6.16 \mathrm{~A}$ & 4.27B & 3.62B & 3.44B \\
\hline Aroma & 4.40 & 4.14 & NS & $6.83 \mathrm{~A}$ & $4.08 \mathrm{~B}$ & $3.17 \mathrm{C}$ & $2.99 \mathrm{C}$ \\
\hline Flavour & $4.70 \mathrm{~A}$ & $4.24 \mathrm{~B}$ & & $6.00 \mathrm{~A}$ & $4.15 B$ & $3.86 \mathrm{~B}$ & $3.46 \mathrm{~B}$ \\
\hline Pulp Colour & 4.31 & 4.43 & NS & $6.83 \mathrm{~A}$ & $3.73 \mathrm{~B}$ & $3.73 \mathrm{~B}$ & $3.59 \mathrm{~B}$ \\
\hline
\end{tabular}

Means not sharing similar letters are significantly different $(\mathrm{P} \leq 0.05)$; NS $=$ non-significant.

Table 6 Effect of different post shipment stages on physical quality characteristics of mango cv. 'Sufaid Chaunsa'

\begin{tabular}{l|cc}
\hline \multicolumn{1}{c|}{ Physical Quality } & \multicolumn{2}{c}{ Stages } \\
\cline { 2 - 3 } Characteristics & At Removal & At Ripening \\
\hline Colour (Score) & $2.75 \mathrm{~B}$ & $3.78 \mathrm{~A}$ \\
Softness (Score) & $2.24 \mathrm{~B}$ & $3.61 \mathrm{~A}$ \\
Disease Severity (Score) & $0.96 \mathrm{~B}$ & $1.75 \mathrm{~A}$ \\
Weight Loss (\%) & $2.90 \mathrm{~B}$ & $6.68 \mathrm{~A}$ \\
Respiration Rate & $2.21 \mathrm{~B}$ & $3.16 \mathrm{~A}$ \\
\hline
\end{tabular}

$* \mathrm{CO}_{2}\left(\mathrm{~m} . \mathrm{mole} \mathrm{kg}^{-1} \mathrm{~h}^{-1}\right)$, Means not sharing similar letters are significantly different $(\mathrm{P} \leq 0.05)$.

\section{Discussion}

Ripening is part of the natural senescence of fruit. Changes during fruit ripening include change in peel and flesh colour and decrease in firmness with increase in fruit softness (Brecht and Yahia, 2009). Skin colour and firmness are the most important factors that determine the mango fruit quality. Long term storage enhanced gradual loss of green colour and softness in mango fruit. During ripening of green mango fruit chlorophyll is degenerated due to various metabolic activities which leads to development of yellow colour linked with carotenoids development (Doreyappa-Gowda and Huddar, 2001). Softening results in the breakdown of cell wall polymers by various cell wall degrading enzymes (Paliyath and Droillard, 1992). Reduction in fruit firmness might be due to the breakdown of insoluble pectic substances to soluble forms by a series of physicochemical changes that are caused by the action of pectic enzymes i.e. esterase and polygalacturonidase during ripening (Weichmann, 1987). In our study, bagged fruit were found to be greener and firmer with lower disease incidence as compared to unbagged ones. These results are in accordance with the findings of Yahia (2006) who reported that colour development of mango fruit was delayed by using MA packaging. Less colour development could be due to the slowing down of various metabolic activities responsible for chlorophyll breakdown (Doreyappa-Gowda and Huddar, 2001). Similarly, fruit colour development was retarded under modified atmosphere storage (Miller et al., 1986; Yantarasri et al., 1995). Fruit removed from cold storage had least score for peel colour. Peel colour development increased during the ripening process at ambient temperature and maximum colour development was observed at final ripening day. Loss of green colour, along with fruit softening could be due to the changes in cell wall composition (Nasrijal, 1993). During ripening process of mango fruit, change in peel colour is actually due to the disappearance of chlorophyll and the appearance of other pigments. Chloroplasts are transformed to chromoplasts containing yellow or red pigments (Lizada, 1993). Nasrijal (1993) has earlier reported that the mango fruit retains its firmness when placed in MAP. Fruit textural softness of the stored mango fruit increased as the storage duration prolonged. Fruit firmness also decreased with advancement in ripening process. Mango fruit were found firmer after their removal from cold storage. Firmness decreased during ripening process and higher softness score was recorded on final day of fruit ripening.

It was observed that bagging of fruit significantly helped in reducing the disease development as compared with non-bagged fruit. Fruit at removal from storage were free from disease. However, a significant increase in disease development was observed as the storage duration was prolonged. Moreover, disease progressed after ethylene exposure and maximum score for disease development was recorded in fruit at final ripening day. Disease incidence was found lesser at removal stage which could be possibly due to the application of fungicide and hot water treatment. Fungicidal application along with hot water treatment is reported to suppress the disease incidence during mango storage, to acceptable levels as reported by many researchers (Coates et al., 2008; Dang et al., 2008). These results are in accordance with the findings of Yahia (1998) who reported that hot water treatment along with Sportak or Thiabendazole application reduced the disease incidence during storage of mango.

Low temperature slows down the respiration process and thereby lowers the $\mathrm{CO}_{2}$ and ethylene production. Mango is a climacteric fruit, showing a climacteric pattern of respiration and an increase in ethylene production during ripening (Reddy and Srivastava, 1999; Lalel et al., 2003). Respiration is declined and is maintained at a low rate until fruit ripening begins. The 
rise in respiration during the climacteric peak is related to fruit ripening (Brecht and Yahia, 2009). Mango fruit ripening is accompanied by increase in ethylene production, which coordinates the ripening process (Mattoo and Modi, 1969). Fruit stored in MA packaging showed reduced $\mathrm{CO}_{2}$ production compared to the unbagged fruit. It was also observed that respiration rate of fruit increased with increase in storage durations. Respiration rate was also found to increase with the advancement in ripening process. Minimum respiration rate was found in fruit at removal from cold storage. However, $\mathrm{CO}_{2}$ production increased during ripening process and maximum $\mathrm{CO}_{2}$ production was observed in fruit at final ripening day. Mango is a climacteric fruit and continues to respire even after its detachment from the parent plant. Respiration process produces $\mathrm{CO}_{2}$ which initiates the ethylene production for further ripening (Brecht and Yahia, 2009). Increase in $\mathrm{CO}_{2}$ production with extended storage has been reported earlier by many researchers (Burg and Burg, 1962; Burdon et al., 1996). Respiration rate declined during cold storage of mango allowing mango to produce little $\mathrm{CO}_{2}$. However after ethylene exposure, shifting of mangoes to high temperature makes mango to respire at faster rate (Mattoo and Modi, 1969; Lalel et al., 2003).

Weight loss is considered mainly due to respiration and transpiration through fruit surface and other biological changes which are taking place in fruit (Kader, 2006). Abbasi et al. (2009) also reported that weight loss of mango fruit increased as the storage period was increased. Weight loss was found to increase as the storage period was prolonged in case of Sindhri. Respiration and transpiration are main reasons for reduction in weight during long term storage due to various anabolic and catabolic processes taking place in mango fruit. Respiration plays a central role in the overall metabolism of a plant and it is therefore often used as a general measure of metabolic rate (Kelany et al., 2010).

Bagged fruit had low TSS value as compared to unbagged fruit due to low respiration and delayed ripening in bagged fruit. Due to low respiration rate, ripening was delayed which further delayed the conversion of carbohydrates into sugars thereby showing a decreased TSS value. Low acidity percentage in bagged fruit could be due to least conversion of starch into sugars which can be attributed to slower ripening in bagged fruit. These results are in accordance with the findings of Kelany et al., (2010) who reported that fruit stored in MAP bags exhibited lower titratable acidity as compared to control fruit. Decrease in acidity percentage during extended storage has been reported by Kelany et al. (2010), which could be due to the substantial loss of organic acids during prolonged storage (Brecht and Yahia, 2009). TSS: TA ratio basically describes the taste of fruit (Rathore et al., 2010). During ripening, break down of starch into soluble sugars occurs with a proportional increase in sugar content (Rathore et al., 2010). Increase in soluble sugars is a major change during mango fruit ripening and sweetness is the most important compositional change related to mango flavour. While starch content increases in chloroplasts during mango fruit development, it is almost completely hydrolysed to simple sugars during ripening (Kumar et al., 1994; Ito et al., 1997). Decrease in sugar content, as storage period is increased, is due to the utilisation of these sugars in various metabolic processes which are still occurring in the fruit even after their detachment from the parent plant (Hulume, 1971). In general ascorbic acid and acidity content showed inverse relationship with the storage period. Similar results were reported by Kelany et al. (2010) where acidity and ascorbic acid content decreased with extended storage period. Brecht and Yahia (2009) also reported that during storage, mango fruit experienced a substantial loss of organic acids. Increase in sugar acid ratio could be linked with breakdown of starch into water soluble sugars during ripening along with increase in sugar acid ratio (Rathore et al., 2010). As the ripening advances, starch content are hydrolysed completely into simple sugars and these are further utilised by fruit itself for various metabolic activities thereby decreasing the sugar content and indirectly the taste of fruit (Kumar et al., 1994; Rathore et al., 2010). Brecht and Yahia (2009) found gradual loss of vitamin $\mathrm{C}$ and other organic acids in mangoes by increasing the storage period. The increase in sugar contents due to the increased starch hydrolysis (Kelany et al., 2010). Decrease in sugar content as the storage period is increased, could be due to the utilisation of these sugars in various metabolic processes which are still occurring in fruit even after their detachment from the parent plant (Hulume, 1971).

\section{Conclusion}

Modified atmosphere storage has significant relationship with physico-chemical fruit quality, market value and consumer acceptability. By using MAP marketability can be improved during long term sea shipping of mangoes. It was observed that bagging can only suppress the disease development to some extent at ripening; however fruit with skin bruises and damages must be avoided for bagging. Sindhri fruit treated with hot water and fungicide and stored at $11^{\circ} \mathrm{C}$ performed better due to higher percentage of marketable fruit with more TSS: TA ratio and good peel colour and less disease development along with good market value. Storage and shelf-life of Sufaid Chaunsa can be increased with careful disease management. Careful harvesting and proper postharvest handling and management are prerequisites for MA storage of mango fruit to achieve best results. Disease development especially in case of Sufaid Chaunsa during long term storage is an issue of concern which needs to be addressed in future studies.

\section{Acknowledgement}

We gratefully acknowledge the financial support of Australian Centre for International Agricultural Research (ASLP-Mango Supply Chain) and METRO Cash and Carry Pakistan Limited for these studies. 


\section{References}

Abbasi NA, Iqbal Z, Maqbool M, Hafiz IA. 2009. Postharvest quality of mango (Mangifera indica L.) fruit as affected by chitosan coating. Pakistan Journal of Botany, 41: 343-357.

Amin M, Malik AU, Din N, Jabbar A, Ahmad I. 2007. Mango soft nose disorder and fruit quality in relation to pre- and postharvest treatments. Life Sciences International Journal, 1: 455-462.

Anonymous, 2010. Mango: Botany and Taxonomy. Available at: http://horticultureworld.net/botany-taxonomy.htm. Date of visit: December 4, 2010.

Beaudry RM, Cameron AC, Shirazi A, Dostal-Lange DL. 1992. Modified-atmosphere packaging of blueberry fruit: Effect of temperature on package oxygen and carbon dioxide. Journal of the American Society for Horticultural Science, 117: 436-441.

Brecht JK, Yahia EM. 2009. Postharvest Physiology. In: The Mango: Botany, Production and Uses. RE Litz. $2^{\text {nd }}$ Edition. CAB International, pp. 493.

Burdon J, Dori S, Marinansky R, Pesis E. 1996. Acetaldehyde inhibition of ethylene biosynthesis in mango fruit. Postharvest Biology and Technology, 8: 153-161.

Burg SP, Burg EA. 1962. Role of ethylene in fruit ripening. Plant Physiology, 37: 179-189.

Coates LM, Johnson GI, Cooke AW. 2008. Postharvest disease control in mangoes using high humidity hot air and fungicide treatments. Annuals of Applied Biology, 12: 441-448.

Dang KT, Singh Z, Swinny EE. 2008. Impact of postharvest disease control methods and cold storage on volatiles, color development and fruit quality in ripe 'Kensington Pride' mangoes. Journal of Agricultural and Food Chemistry, 56: 10667-10674.

Davies AR. 1995. Advances in Modified-Atmosphere Packaging, New Methods of Food Preservation, (ed.) GW Gould, Glasgow, UK, Blackie, pp. 304-320.

Day BPF. 1989. Extension of shelf-life of chilled food. European Food and Drink Review, 4: 47.

Day BPF. 1990. Perspective of modified atmosphere packaging of fresh produce in Western Europe. Proceedings of CAP 90, Fifth International Conference on Controlled/Modified Atmosphere/Vacuum Packaging, San Jose, CA. Schotland Business Research, Princeton, NJ.

Doreyappy-Gowda IND, Huddar AG. 2001. Studies on ripening changes in mango (Mangifera indica L.) fruits. Journal of Food Science and Technology, 3: 135-137.

Hafeez O, Malik AU, Khan AS, Rehman A, Javaid QA. 2012. Impact of different packaging types and low temperature shipping durations on fruit quality and marketability of Pakistani mangoes. International Journal of Agriculture and Biology, 14: 47-54.

Hulume AC. 1971. The mango. The Biochemistry of Fruits and their Products. Academic Press, London and New York, USA.

Ito T, Sasaki K, Yoshida Y. 1997. Changes in respiration rate, saccharide and organic acid content during the development and ripening of mango fruit (Mangifera indica L. 'Irwin') cultured in a plastic house. Journal of the Japanese Society for Horticultural Science, 66: 629-635.

Johnson P, Amin M, Dunne T, Khooharo MM. 2013. Implementing CA shipping supply chains for Sindh mango growers. Australian Aid Funded, ASLP II. Mango Value Chain Improvement Project.

Kader AA. 1994. Modified and controlled atmosphere storage of tropical fruit. In: Champ BR, Highley E, Johnson GI (ed.), ACIAR Proceedings Volume 50: Postharvest Handling of Tropical Fruit, Thailand, pp. 239-249.
Kader AA. 2006. The return of investment in postharvest technology for assuring quality and safety of horticultural crops. Department of Plant Science, University of California Davis, CA 95616, USA.

Kelany AE, Sahar M, Wahab A, Abdel-Hafee AA, Osman MT. 2010. Using modified atmosphere and different temperatures for storing 'Kent' mango fruit. Journal of Horticultural Science \& Ornamental Plants, 2: 46-56.

Kumar S, Das DK, Singh AK, Prasad US. 1994. Sucrose metabolism during maturation and ripening of mango cultivars. Plant Physiology and Biochemistry, 21: 27-32.

Lalel HJD, Singh Z, Tan SC. 2003. Maturity stage at harvest affects fruit ripening, quality and biosynthesis of aroma volatile compounds in 'Kensington Pride' mango. Journal of Horticultural Science and Biotechnology, 78: 225-233.

Lizada C. 1993. Mango. In: Seymour GS, Taylor IE, Tucker GA (eds.) Biochemistry of Fruit Ripening. Chapman and Hill, London, pp. 255-271.

Malik AU, Singh Z. 2005. Prestorage application of polyamines improves shelf life and fruit quality of mango. Journal of the American Society for Horticultural Science, 129: 280-286.

Mattoo AK, Modi VV. 1969. Ethylene and ripening of mangos. Plant Physiology, 44: 308-310.

Miller WR, Spalding DH, Hale PW. 1986. Film wrapping mangoes at advancing stages of post-harvest ripening. Tropical Science, 26: 9-17.

Nasrijal NH. 1993. Effect of storage temperature on pectin depolymerization and softening of mango fruit. Journal of Horticultural Sciences, 59: 283-286.

Parry RT. 1993. Principles and applications of MAP of foods. Blackie Academic \& Professional, England. 1-132.

Paliyath G, Dorillord MJ. 1992. The mechanism of membrane discolouration and disassembly during senescence. Plant Physiology and Biochemistry, 30: 789-812.

Peryam DR, Pilgrim EJ. 1957. Hedonic scale method for measuring food preferences. Food Technology, 11: 9-15.

Rathore HA, Masud T, Raza A, Rizwan M. 2010. Potential techniques of interactive packaging in cardboard carton and their effect on overall quality characteristics such as sugars, colour, texture, taste and flavour of Chaunsa White variety of Mango at ambient temperature during storage. Pakistan Journal of Nutrition, 9: 343-351.

Reddy YV, Srivastava GC. 1999. Ethylene biosynthesis and respiration in mango fruits during ripening. Indian Journal of Plant Physiology, 4: 32-35.

Rodov V, Fishman S, De la Asuncion R, Peretz J, Ben-Yehoshua S. 1997. Modified atmosphere packaging (MAP) of 'Tommy Atkins' mango in perforated film. Acta Horticulturae, 455: 654661 .

Tharanathan RN, Yashoda HM, Prabha TN. 2006. Mango (Mangifera indica L.), "The King of Fruits". An Overview. Food Reviews International, 22: 95-123.

Weichmann J. 1987. Postharvest Physiology of Vegetables. Marcel Bekker, Inc, New York, P. 145.

Yahia EM. 1998. Postharvest Handling of Mango. Available at: http://www.manarasoft.com/pdf/P85.pdf. Date of visit. February 7, 2011.

Yahia EM. 2006. Modified and controlled atmospheres for tropical fruits. Stewart Postharvest Reviews, 5: 6-10.

Yantarasri T, Ben-Yehoshua S, Rodov V, Kumpuan W, Uthaibutra J, Sornsrivichai J. 1995. Development of perforated modified atmosphere package for mango. Acta Horticulturae. 398: 81-92. 